\title{
IMPACTOS DA DECISÃO DA SUPREMA CORTE DOS ESTADOS UNIDOS NA PROTEÇÃO DO PATRIMÔNIO GENÉTICO HUMANO: caso Association for Molecular Pathology vs. Myriad Genetics
}

\section{THE IMPACTS OF THE UNITED STATES SUPREME COURT'S DECISION ON THE HUMAN GENETIC HERITAGE PROTECTION: Association for Molecular Pathology vs. Myriad Genetics case}

\begin{abstract}
BEATRIZ SOUZA COSTA
Mestre e Doutora em Direito Constitucional pela UFMG. Professora de Direito Ambiental Constitucional do Curso de Pós-Graduação em Direito Ambiental e Desenvolvimento Sustentável da Escola Superior Dom Helder Câmara. PróReitora de Pesquisa da ESDHC. biaambiental@yahoo.com.br
\end{abstract}

NATHALIA BAStos do VALE BRITO Mestranda em Direito Ambiental e Desenvolvimento Sustentável pela Escola Superior Dom Helder Câmara, em Belo Horizonte, Minas Gerais, graduada em Direito pela PUC-Minas, integrante do CEBID-Centro de Estudos em Biodireito -

Dom Helder.

nathaliabvbrito@gmail.com

\begin{abstract}
RESUMO
O presente artigo analisa a decisão da Suprema Corte dos Estados Unidos, que invalidou as patentes sobre material genético humano de titularidade dos laboratórios Myriad. Questiona-se os impactos dessa decisão na proteção do patrimônio genético humano, considerando-o como integrante do meio ambiente, à luz das considerações bioéticas. O objetivo geral é a busca pela resposta a essa indagação sendo utilizado, para tanto, o raciocínio dedutivo-indutivo, valendo-se da técnica da pesquisa bibliográfica e do estudo de caso. Através da análise de considerações bioéticas acerca da importância de tal decisão na proteção do patrimônio genético humano, conclui-se que este não deve ser tratado como completamente intangível, mas que pode, segundo limites jurídicos e éticos, ser utilizado de forma a garantir a dignidade da pessoa humana e o meio ambiente equilibrado. Assim, a decisão da Suprema Corte auxiliou nessa garantia ao invalidar uma patente claramente indevida e sem obedecer aos requisitos legais.
\end{abstract}

Palavras-chave: patrimônio genético humano; biodiversidade; patentes; bioética.

\begin{abstract}
This article examines the United States Supreme Court's decision that invalidated patents on human genetic material held by Myriad laboratories. It raises the question about the impact of this decision on the protection of the human genetic heritage, considering it as part of the environment, in light of bioethical considerations. The overall goal is the search for the answer to this question using, for that, the deductiveinductive logic and the bibliographic research technique. Through the analysis of bioethics lessons about the importance of such decision at protecting the human genetic heritage, it is obvious that the human genetic heritage should not be treated as completely intangible, but, according to legal and ethical limits, it can be used to ensure the dignity of the human person and the balanced environment. Therefore, the Supreme Court's decision helped to guarantee this dignity by invalidating a patent clearly improper and incompatible with legal requirements.
\end{abstract}

Keywords: human genetic heritage; biodiversity; patentes; bioethics. 
IMPACTOS DA DECISÃO DA SUPREMA CORTE DOS ESTADOS UNIDOS NA PROTEÇÃO DO PATRIMÔNIO GENÉTICO HUMANO: caso Association for Molecular Pathology vs. Myriad Genetics

Beatriz Souza Costa, nathalia Bastos do Vale Brito

\section{SUMÁRIO}

INTRODUÇAO; 1 PATRIMÔNIO GENÉTICO HUMANO E MEIO AMBIENTE; 2 ANÁLISE DO CASO ASSOCIATION FOR MOLECULAR PATHOLOGY VS. MYRIAD GENETICS; 2.1 Myriad Genetics e suas patentes sobre DNA humano isolado: uma contextualização; 2.2 Decisão da Suprema Corte dos Estados Unidos: a mudança de um paradigma; 2.3 Invalidação das patentes sobre DNA isolado e proteção do patrimônio genético humano: considerações bioéticas; CONCLUSÃO; REFERÊNCIAS.

\section{INTRODUÇÃO}

A busca por conhecimento é um anseio inerente ao ser humano já que este procura não só atender as suas necessidades básicas e essenciais, mas também procura satisfazer a sua curiosidade acerca do mundo à sua volta. Para tanto, o homem, desde os primórdios de sua história, vem utilizando o conhecimento técnico-científico para conhecer e transformar a realidade vivida, na medida em que faz descobertas de leis da natureza e aplicação prática dos processos, produtos e inventos desenvolvidos por ele. Neste âmbito, percebe-se que o conhecimento técnico-científico vem evoluindo de forma exponencial, especialmente a partir do século XX, resultando em novas tecnologias que tem a capacidade de alterar significativamente 0 ambiente em que vivemos.

Juntamente com essa evolução, tem-se em contrapartida o aparecimento de diversas questões e polêmicas, principalmente as que se relacionam com o meio ambiente e sua degradação, o que demanda uma nova forma de encarar o uso da tecnologia para que se possa alcançar a sustentabilidade em suas práticas, aliada a uma visão mais humana e consoante à bioética.

O entrelaçamento entre a tecnologia e a questão ambiental é inegável, podendo-se considerar que um dos aspectos mais relevantes desta relação é o impacto da tecnologia no patrimônio genético, através do desenvolvimento de pesquisas e manipulações genéticas que geram muitos questionamentos, devido ao fato de que tais práticas afetas à biotecnologia são muito dinâmicas e complexas, demandando que o Direito se atualize para oferecer uma tutela adequada, justa e eficaz às novas situações que vão surgindo.

Uma dessas situações é a relação entre a propriedade intelectual e a biotecnologia, assunto que demanda uma análise interdisciplinar tendo em vista sua abrangência e desdobramentos. Dentre estes, tem-se a possibilidade do patenteamento do material genético 
IMPACTOS DA DECISÃO DA SUPREMA CORTE DOS ESTADOS UNIDOS NA PROTEÇÃO DO PATRIMÔNIO GENÉTICO HUMANO: casO Association for Molecular Pathology vs. Myriad Genetics

Beatriz Souza Costa, nathalia Bastos do Vale Brito

humano, tema complexo que suscita questões de cunho jurídico, econômico, ético e social, impondo ao Direito a adoção de um caráter sempre aberto ao diálogo, baseando-se na discussão dos instrumentos jurídicos atuais e buscando sempre um aperfeiçoamento e adequação das interpretações jurisprudenciais na análise dos casos concretos.

As decisões judiciais a respeito de patentes sobre o genoma humano desempenham papel fundamental na interpretação e na possibilidade de sua concessão, impondo-se neste artigo a análise da decisão da Suprema Corte dos Estados Unidos que invalidou as patentes sobre DNA humano isolado de titularidade dos laboratórios Myriad Genetics, o que representou uma quebra de paradigma, mudando totalmente a concepção adotada pelos Estados Unidos acerca das patentes biotecnológicas. Neste âmbito, indaga-se: qual o impacto dessa decisão na proteção do patrimônio genético humano, considerando-o como integrante da biodiversidade?

O objetivo geral deste trabalho é, considerando as justificativas e o cenário social e jurídico apontado acima, analisar qual o impacto da invalidação das patentes sobre DNA humano isolado na proteção do patrimônio genético humano, considerando a sua importância ambiental.

Para tanto, busca-se demonstrar que o patrimônio genético humano é integrante da biodiversidade e, portanto, de essencial importância para o direito ambiental. Necessário é também analisar o contexto no qual surgiram as patentes dos laboratórios Myriad Genetics e seu impacto jurídico e social, culminando na análise da decisão da Suprema Corte que as invalidou. Por fim, avalia-se, sob o viés da bioética, como tal decisão impactou na proteção do patrimônio genético humano como elemento do meio ambiente. A metodologia adotada foi o raciocínio dedutivo-indutivo e o estudo de caso, utilizando-se a técnica da pesquisa bibliográfica, analisando-se fontes nacionais e estrangeiras sobre direito ambiental, bioética e propriedade intelectual.

0 artigo abordará, primeiramente a relação entre patrimônio genético humano e meio ambiente, explicando como este constitui-se em parte integrante da biodiversidade. Em segundo lugar, apresenta-se o caso judicial Association for Molecular Pathology vs. Myriad Genetics Inc., abordando o contexto do surgimento de tal disputa, seguido da análise da decisão final da Suprema Corte e, por fim, avalia-se o impacto desta para a proteção do patrimônio genético humano.

\section{PATRIMÔNIO GENÉTICO HUMANO E MEIO AMBIENTE}


IMPACTOS DA DECISÃO DA SUPREMA CORTE DOS ESTADOS UNIDOS NA PROTEÇÃO DO PATRIMÔNIO GENÉTICO HUMANO: caso Association for Molecular Pathology vs. Myriad Genetics

Beatriz Souza Costa, nathalia Bastos do Vale Brito

0 patrimônio genético humano pode ser considerado como matéria de interesse ambiental, na medida em que faz parte da biodiversidade e, consequentemente, do meio ambiente. Este pode ser entendido, segundo o artigo $3^{\circ}$ da Lei $6.938 / 81^{1}$, como “o conjunto de condições, leis, influências e interações de ordem física, química e biológica, que permite, abriga e rege a vida em todas as suas formas", e constitui-se num conceito amplo, que envolve tanto os ecossistemas naturais e as suas interações bióticas e abióticas, quanto os ecossistemas artificiais criados pelo homem, envolvendo as suas relações sociais, culturais, laborais e políticas.

A biodiversidade é parte integrante e necessária do meio ambiente, constituindo-se no elemento biótico - o elemento que possui vida - dos ecossistemas naturais, já que ela envolve a pluralidade de espécies vivas de todas as origens e suas relações intrínsecas e indissociáveis, implicando na vinculação profunda, necessária e solidária existente entre esses seres para manter o nexo orgânico e o equilíbrio dos ecossistemas. ${ }^{2}$

A biodiversidade traz em si a concepção de patrimônio genético como parte integrante de sua composição, sendo este entendido, segundo o artigo $2^{\circ}$, I da Lei $n^{\circ} 13.123$ de 2015, como uma informação de origem genética, ou seja, substâncias ou moléculas que estão contidas das diversas espécies animais, vegetais, microbianas ou fúngicas que compõem a biodiversidade, ou que são provenientes de seu metabolismo ${ }^{3}$, ou seja, é a unidade básica que desencadeia na complexidade dos seres vivos na medida em que ela comanda e regulariza a produção de proteínas e outras substâncias que culminarão nas características fenotípicas essenciais de cada organismo vivo.

Nesse âmbito, importante se faz tecer algumas considerações a respeito dos recursos genéticos, que são os elementos da diversidade genética, ou seja, a variabilidade de genes entre

\footnotetext{
${ }^{1}$ BRASIL. Lei n. 6.938, de 31 de agosto de 1981. Dispõe sobre a Política Nacional do Meio Ambiente, seus fins e mecanismos de formulação e aplicação, e dá outras providências. Diário Oficial da União, Brasília, 31 ago. de 1981. Disponível em: <http://www.planalto.gov.br/ccivil_03/Leis/L6938.htm> Acesso em: 01 out. 2015.

${ }^{2}$ MILARÉ, ÉDIS. Direito do ambiente. 9. ed. São Paulo: Revista dos Tribunais, 2014. p. 1027.

${ }^{3}$ BRASIL, Lei n. 13.123, de 20 de maio de 2015. Regulamenta o inciso II do $\S 1^{\circ}$ e o $\S 4^{\circ}$ do art. 225 da Constituição Federal, o Artigo 1, a alínea $j$ do Artigo 8, a alínea c do Artigo 10, o Artigo 15 e os $\S \S 3^{\circ}$ e $4^{\circ}$ do Artigo 16 da Convenção sobre Diversidade Biológica, promulgada pelo Decreto $\mathrm{n}^{\circ} 2.519$, de 16 de março de 1998; dispõe sobre o acesso ao patrimônio genético, sobre a proteção e o acesso ao conhecimento tradicional associado e sobre a repartição de benefícios para conservação e uso sustentável da biodiversidade; revoga a Medida Provisória no 2.186-16, de 23 de agosto de 2001; e dá outras providências. Diário Oficial da União, Brasília, 20 de maio de 2015. Disponível em: < http://www.planalto.gov.br/ccivil_03/_Ato2015-2018/2015/Lei/L13123.htm\#art50 > Acesso em: 26 nov. 2015.
} 
IMPACTOS DA DECISÃO DA SUPREMA CORTE DOS ESTADOS UNIDOS NA PROTEÇÃO DO PATRIMÔNIO GENÉTICO HUMANO: casO Association for Molecular Pathology vs. Myriad Genetics

Beatriz Souza Costa, nathalia Bastos do Vale Brito

as espécies e dentro delas, que possuem valor e que podem ser benéficos ao ser humano ${ }^{4}$. Ambas as concepções de patrimônio genético quanto a de recursos genéticos são objetos de tutela dos mais diversos instrumentos jurídicos, tanto de âmbito nacional quanto internacional, o que é consequência de sua crescente importância e das suas implicações econômicas, sociais, ambientais e bioéticas.

O crescimento da importância econômica do patrimônio genético dá-se principalmente pela sua estreita relação com a biotecnologia que é o ramo da ciência que aplica certas técnicas para produzir produtos através da utilização de organismos vivos, que tem como um de seus campos específicos a engenharia genética que trabalha com os recursos genéticos, especialmente o DNA, possuindo ampla aplicação em setores ligados à medicina, à farmácia, à indústria de cosméticos, à indústria alimentícia, à agricultura, à pecuária e ao meio ambiente, o que demonstra o seu expressivo valor econômico ${ }^{5}$.

Cabe salientar que o patrimônio genético humano também está contido na definição de patrimônio genético, já que este abrange todas as categorias de seres vivos. Assim, é possível entender que o homem e sua composição genética constituem-se em elementos da biodiversidade e, consequentemente, é um componente do meio ambiente.

Uma das razões de se adotar tal entendimento encontra-se na gradual superação do posicionamento antropocêntrico exacerbado para se considerar as teorias do chamado ecocentrismo, compreendendo o homem como integrante da natureza e não somente um ser autônomo e autossuficiente que a domina e a subjuga conforme os seus interesses.

A discussão acerca do conflito entre antropocentrismo e ecocentrismo é profunda e densa, não sendo possível desenvolvê-la no âmbito deste artigo. Então, em termos gerais, o antropocentrismo é uma visão de mundo que tem como uma de suas bases o pensamento racional ocidental que considera a racionalidade humana como "valor maior e determinante da finalidade das coisas" ${ }^{6}$, entendendo-se que o ser humano, por ser portador da razão, pode ser considerado como centro do universo, ou seja, o centro dos interesses, sendo referência absoluta de valores e, no que concerne ao meio ambiente, o antropocentrismo traz a ideia de que o homem é um ser superior e autônomo, que pode utilizar, da forma que achar melhor, dos recursos naturais pois ele tem o domínio sobre estes. Tal concepção levou a consequências

\footnotetext{
${ }^{4}$ GUNERATNE, Camena. Genetic resources, equity and international law. Massachusetts: Edward Elgar Publishing, 2012. p. 7.

${ }^{5}$ IACOMINI, Vanessa. Os direitos de propriedade intelectual e a biotecnologia. In: IACOMINI, Vanessa (coord.). Propriedade intelectual e biotecnologia. Curitiba: Juruá, 2009. p. 16.

${ }^{6}$ MILARÉ, Édis. Direito do Ambiente. p. 106.
} 
IMPACTOS DA DECISÃO DA SUPREMA CORTE DOS ESTADOS UNIDOS NA PROTEÇÃO DO PATRIMÔNIO GENÉTICO HUMANO: caso Association for Molecular Pathology vs. Myriad Genetics

Beatriz Souza Costa, nathalia Bastos do Vale Brito

drásticas, principalmente no que se refere à desvalorização do valor intrínseco da natureza e sua importância na manutenção do equilíbrio da vida na terra, gerando uma subjugação da biodiversidade e dos demais recursos naturais às necessidades mais imediatas do homem, que causaram e que ainda causam consequências graves ${ }^{7}$.

Há portanto um descontentamento com relação a essa visão de mundo, fato que abriu os caminhos para o desenvolvimento de teorias alternativas que consideram o homem como parte integrante do meio ambiente. 0 ecocentrismo vem nessa direção, entendendo que o mundo não existe somente para a satisfação das necessidades do homem, mas, em contrapartida, o homem possui deveres para com a natureza - que possui valor intrínseco - na medida em que ele se enxerga como parte integrante dessa ${ }^{8}$. A proteção da natureza é um dever inarredável, pois, dentre outros fatores, ela é condição da manutenção da vida do próprio homem na terra. Assim, o homem pode ser visto como elemento da natureza, fazendo parte de seus processos e fluxos, desempenhando funções para a manutenção do nexo orgânico e do equilíbrio ambiental.

Ademais, a visão de que o patrimônio genético humano é parte integrante do meio ambiente também é clara quando a Constituição, quando trata da tutela ambiental, traz a necessidade de se tutelar a diversidade e integridade do patrimônio genético:

Art. 225. Todos têm direito ao meio ambiente ecologicamente equilibrado, bem de uso comum do povo e essencial à sadia qualidade de vida, impondo-se ao Poder Público e à coletividade o dever de defendê-lo e preservá-lo para as presentes e futuras gerações.

$\S 1^{\circ}$ Para assegurar a efetividade desse direito, incumbe ao Poder Público:

II - preservar a diversidade e a integridade do patrimônio genético do País e fiscalizar as entidades dedicadas à pesquisa e manipulação de material genético; ${ }^{9}$

Percebe-se que a Constituição elencou como um dever do Poder Público a fiscalização das entidades dedicadas à pesquisa e manipulação do material genético, considerando tal dever como essencial para assegurar a efetividade do direito ao meio ambiente ecologicamente equilibrado corroborando assim a concepção de que o patrimônio genético é um elemento integrante do meio ambiente e que sua proteção é essencial à manutenção da qualidade de vida do ser humano. Incumbe salientar que, de acordo com o exposto a respeito do patrimônio

\footnotetext{
${ }^{7}$ MILARÉ, Édis. Direito do Ambiente. p. 107.

8 RAMOS, Ana Virgínia Gabrich Fonseca Freire. Manipulação da vida humana e meio ambiente. Dissertação (Mestrado em Direito) - Escola Superior Dom Helder Câmara, Belo Horizonte, 2014. p. 27-28.

9 BRASIL. Constituição (1988) Constituição da República Federativa do Brasil. Brasília, 5 out. 1988. Disponível em: < http://www.planalto.gov.br/ccivil_03/constituicao/ConstituicaoCompilado.htm> Acesso em: 01 out. 2015.
} 
IMPACTOS DA DECISÃO DA SUPREMA CORTE DOS ESTADOS UNIDOS NA PROTEÇÃO DO PATRIMÔNIO GENÉTICO HUMANO: caso Association for Molecular Pathology vs. Myriad Genetics

Beatriz Souza Costa, nathalia Bastos do Vale Brito

genético, resta evidente que o significado desta expressão no texto constitucional tem um caráter amplo, englobando o patrimônio genético humano.

Celso Antônio Pacheco Fiorillo ${ }^{10}$ adota posição semelhante, considerando que o patrimônio genético humano tem proteção ambiental constitucional, o que se fundamenta não só no artigo em comento, mas também pelo fato de a Constituição elencar a dignidade da pessoa humana como um de seus fundamentos. Ademais, ao considerar o meio ambiente como bem ambiental, que é de uso comum do povo e essencial à qualidade de vida, a Constituição tutela, portanto, a dignidade da pessoa humana e a necessidade de se garantir uma vida digna.

Tendo em vista o que foi acima explicitado, é possível entender que:

A partir do momento em que o homem se vê como parte da natureza, todo e qualquer tipo de intervenção, principalmente aquelas que ocorrem diretamente no organismo humano, passam a ser intervenções na própria natureza, trazendo riscos, vantagens e desvantagens, ou seja, impactando de diferentes maneiras o meio ambiente. ${ }^{11}$

Concebe-se então que a tutela do patrimônio genético humano, assim como as suas implicações jurídicas, sociais, econômicas e bioéticas é de essencial importância ao direito ambiental, devendo ser objeto de sua análise, consideração e discussão.

Nesse âmbito, questiona-se a possibilidade do patenteamento do material genético humano, levando-se em consideração os desdobramentos trazidos pela aplicação do regime de propriedade intelectual à biotecnologia genômica, assim como a discussão bioética. Atenta-se ao fato de que as patentes sobre o material genético humano são uma realidade e, neste sentido, busca-se analisar a recente e paradigmática decisão da Suprema Corte dos Estados Unidos no caso Association for Molecular Pathology vs. Myriad Genetics, de junho de 2013 e sua implicação na proteção do patrimônio genético humano.

\section{ANÁLISE DO CASO ASSOCIATION FOR MOLECULAR PATHOLOGY VS. MYRIAD GENETICS}

[...] Eu estou escrevendo sobre isso agora porque espero que outras mulheres possam se beneficiar da minha experiência. [...] hoje é possível descobrir através

${ }^{10}$ FIORILLO, Celso Antônio Pacheco. Curso de Direito ambiental brasileiro. 14. ed. São Paulo: Saraiva, 2014. p. 55.

${ }^{11}$ RAMOS, Ana Virgínia Gabrich Fonseca Freire. Manipulação da vida humana e meio ambiente. p. 28. 
IMPACTOS DA DECISÃO DA SUPREMA CORTE DOS ESTADOS UNIDOS NA PROTEÇÃO DO PATRIMÔNIO GENÉTICO HUMANO: caso Association for Molecular Pathology vs. Myriad Genetics

de um exame de sangue se você é altamente suscetível ao câncer de mama e de ovário, e assim tomar decisões. [...] Câncer de mama sozinho mata 458.000 pessoas a cada ano, de acordo com a Organização Mundial da Saúde, principalmente em países de baixa ou média renda. Deveria ser uma prioridade garantir que mais mulheres possam ter acesso aos testes genéticos e tratamentos preventivos salvadores de vida, quaisquer que sejam seus meios e antecedentes, onde quer que vivam. 0 custo do teste para o BRCA1 e BRCA2, que é de $\$ 3000,00$ nos Estados Unidos, continua sendo um obstáculo para muitas mulheres. (tradução nossa). ${ }^{12} 13$

Este fragmento se refere à carta escrita pela atriz Angelina Jolie ao jornal The New York Times em maio de 2013 na qual ela declara e explica a sua decisão de se submeter a uma dupla mastectomia após ter sido diagnosticada como portadora do gene BRCA1 que é responsável pelo aumento significativo do risco de desenvolver câncer de mama e de ovário. Na carta, Angelina Jolie encoraja as mulheres a buscarem informações acerca da doença e da sua potencial, ou não, predisposição para desenvolvê-la, apontando a sua gravidade e as suas consequências familiares muitas vezes devastadoras.

O grande interesse público de tal declaração colocou em evidência a importância da utilização de testes genéticos para diagnosticar a predisposição a doenças, importante instrumento para viabilizar a medicina preventiva e, consequentemente o direito à saúde.

Entretanto, há muito o que se discutir no que se refere às questões jurídicas, sociais e bioéticas vinculadas ao teste específico no qual foi submetida a atriz, o que se discutirá a seguir.

\subsection{Myriad Genetics e suas patentes sobre DNA humano isolado: uma contextualização}

O Projeto Genoma Humano foi elemento propulsionador para o avanço das pesquisas genéticas. Iniciado em 1990 e finalizado em 2003, consistiu em um projeto de pesquisa internacional que teve como objetivo a investigação, de forma aprofundada, do genoma humano

\footnotetext{
12 JOLIE, Angelina. My medical choice. The New York Times, Nova York, 14 mai. 2014. Disponível em: < http://www.nytimes.com/2013/05/14/opinion/my-medical-choice.html?_r=0> Acesso em: 03 out. 2015.

${ }^{13}$ [...] I am writing about it now because I hope that other women can benefit from my experience. [...] today it is possible to find out through a blood test whether you are highly susceptible to breast and ovarian cancer, and then take action. [...] Breast cancer alone kills some 458,000 people each year, according to the World Health Organization, mainly in low- and middle-income countries. It has got to be a priority to ensure that more women can access gene testing and lifesaving preventive treatment, whatever their means and background, wherever they live. The cost of testing for BRCA1 and BRCA2, at more than $\$ 3,000$ in the United States, remains an obstacle for many women.
} 
IMPACTOS DA DECISÃO DA SUPREMA CORTE DOS ESTADOS UNIDOS NA PROTEÇÃO DO PATRIMÔNIO GENÉTICO HUMANO: caso Association for Molecular Pathology vs. Myriad Genetics

Beatriz Souza Costa, nathalia Bastos do Vale Brito

através de seu sequenciamento, mapeamento e descrição ${ }^{14}$. Uma das grandes descobertas proporcionadas por essas pesquisas tem relação com o câncer de mama que pode, dentre outros fatores, ser causado por uma predisposição genética.

Nesse contexto, em 1990 uma equipe de pesquisadores da University of California, Berkeley localizou um gene que está associado ao aumento do risco de se desenvolver câncer de mama e de ovário - o gene BRCA1 - descoberta que gerou o interesse de inúmeros cientistas e impulsionou as companhias de biotecnologia a despender recursos financeiros e tecnológicos para cumprir o desafio de isolar tal gene, sendo que em 1994, a Myriad Genetics Inc. completou tal realização, anunciando o isolamento do gene BRCA1 e em 1995, anunciou o isolamento de outro gene relacionado, o BRCA2 ${ }^{15}$. Assim, o isolamento e o sequenciamento de ambos os genes possibilita o desenvolvimento de testes ${ }^{16}$ para detectar se há mutações naqueles e informar aos pacientes se eles possuem ou não alto risco de desenvolver câncer.

A Myriad, então, buscou proteger seu trabalho por meio de diversos pedidos de patentes, que foram concedidos a partir de 1997, totalizando nove. Estas proporcionaram à Myriad uma grande vantagem no desenvolvimento de pesquisas e a partir dessas, testes para diagnósticos, terapias e medicamentos numa área de grande interesse, concedendo a possibilidade de excluir outros laboratórios de utilizar os genes e os métodos patenteados em suas pesquisas ou submetê-los a necessidade de requerer uma licença, gerando em contrapartida um expressivo ganho financeiro ${ }^{17}$.

A Myriad, portanto, tem grande parte de seu lucro baseado na exploração científica e econômica do material genético humano e, tendo em vista todos os desdobramentos que essa situação pode gerar, pode-se surgir a questão de como foi possível a concessão de tais patentes.

\footnotetext{
${ }^{14}$ NAVES, Bruno Torquato de Oliveira. Direitos de personalidade e dados genéticos: revisão críticodiscursiva dos direitos de personalidade à luz da "natureza jurídica" dos dados genéticos humanos. Belo horizonte: Escola Superior Dom Helder Câmara, ESDHC, 2010. p. 37-40.

${ }^{15}$ RINEHART, Amelia. Myriad lessons learned. University of Utah College of Law Research Paper, n. 87, 2015. p. 6-10. Disponível em: <http://papers.ssrn.com/sol3/papers.cfm?abstract_id=2499789> Acesso em: 23 set. 2015.

${ }^{16}$ Tais testes envolvem diagnósticos genômicos que, conforme salienta a professora americana Amelia Smith Rinehart são desenvolvidos em estágios pré-sintomáticos e baseiam-se nas informações genéticas do paciente ao invés dos sintomas externos, proporcionando o desenvolvimento do que se conhece por "medicina personalizada", um novo e promissor mercado que envolve a elaboração de medicamentos e tratamentos individuais para pacientes.

17 Os testes desenvolvidos a partir dos genes BRCA1 e 2 e a análise dos resultados custa, em média, \$ 3.340,00 por pessoa, sendo uma das mais rentáveis atividades desenvolvidas pela Myriad, que em 2011 acumulou $\$ 400$ milhões, que representa $80 \%$ dos lucros da companhia, na realização de tais testes, segundo pesquisa realizada por Amelia Smith Rinehart.
} 
IMPACTOS DA DECISÃO DA SUPREMA CORTE DOS ESTADOS UNIDOS NA PROTEÇÃO DO PATRIMÔNIO GENÉTICO HUMANO: caso Association for Molecular Pathology vs. Myriad Genetics

Beatriz Souza Costa, nathalia Bastos do Vale Brito

A resposta está na tradição jurídica e jurisprudencial dos Estados Unidos, que sempre se preocupou com o progresso da ciência e com a garantia do direito à exclusividade a autores e inventores, cuja proteção se dá pela propriedade intelectual, sendo que os requisitos para a concessão de uma patente de invenção que são a matéria patenteável, a novidade, a utilidade e a não obviedade ou o ato inventivo. A possibilidade de se patentear organismos vivos tem sido a prática adotada pelos tribunais americanos desde a paradigmática decisão no processo Diamond vs. Chakrabarty em 1980, no qual concordou com a patenteabilidade da bactéria Pseudomonas genus, que por ter sido modificada geneticamente, através de trabalho humano, acrescentou característica nova, tornando-a distinta das bactérias encontradas na natureza ${ }^{18}$. Em tal decisão foi proferida a frase que guiou toda a atividade jurisprudencial nos anos seguintes: "Tudo abaixo do sol que é feito pelo homem é elegível para ser patenteável” (tradução nossa). ${ }^{19} 20$

A partir daí, as patentes biotecnológicas relacionadas a processos ou produtos envolvendo microrganismos, plantas, animais e material genético humano foram concedidas sob o argumento de que são matérias patenteáveis os organismos ou matérias que, manipulados através das técnicas de biotecnologia, passaram a ter novas propriedades físicas ou químicas. Tal entendimento também englobou o material genético humano, que foi considerado como matéria patenteável. Conforme Diretiva do United States Patent and Trademark Office (USPTO) de 2001, o material genético satisfaz as condições de patenteabilidade caso o gene estiver isolado, ou seja, separado de outras moléculas associadas a ele, já que a molécula isolada de DNA é diferente do DNA presente na natureza ${ }^{21}$. Portanto, o simples isolamento do DNA é considerado como ato inventivo.

Percebe-se que as patentes concedidas à Myriad cumprem os parâmetros até então adotados pelos Estados Unidos. Entretanto, tal legalidade não impediu o levantamento de preocupações acerca do impacto dessas patentes, incluindo o alto custo dos testes genéticos e a consequente diminuição na acessibilidade a estes, a impossibilidade de se conseguir uma segunda opinião a respeito do resultado do teste e, ademais, o impacto negativo nas pesquisas

\footnotetext{
${ }^{18}$ A característica em questão é a possibilidade da bactéria degradar hidrocarbonetos, função muito útil no tratamento de vazamento de petróleo nos oceanos.

19 "Anything under the sun that is made by man is eligible for patenting"

20 UNITED STATES. Supreme Court. 447 U.S. 303 (1980). Diamond v. Chakrabarty. Disponível em: < http:/ / caselaw.lp.findlaw.com/cgi-bin/getcase.pl?court=us\&vol=447\&invol=303>Acesso em: 03 out. 2015.

21 UNITED STATES PATENT AND TRADEMARK OFFICE. Guidelines for examination of patente applications under the 35 U.S.C 112, \$1 'Written Description" requirement. Federal Register, v. 66, n. 4, jan. 2001. p. 1093. Disponível em: <http://www.uspto.gov/web/offices/com/sol/notices/writdesguide.pdf>. Acesso em: 20 set. 2015.
} 
IMPACTOS DA DECISÃO DA SUPREMA CORTE DOS ESTADOS UNIDOS NA PROTEÇÃO DO PATRIMÔNIO GENÉTICO HUMANO: caso Association for Molecular Pathology vs. Myriad Genetics

Beatriz Souza Costa, nathalia Bastos do Vale Brito

genéticas, na medida em que as patentes podem impedir que tais pesquisas sejam feitas sem licença do seu detentor ou que elas sejam feitas mediante pagamento.

Esse panorama gerou muitos posicionamentos que buscavam, portanto, a invalidação dessas patentes, principalmente nos Estados Unidos e na Europa. Jordan Paradise ${ }^{22}$ chama atenção ao fato de que os pesquisadores se sentiram limitados pelas patentes pois elas impedem o acesso total às informações contidas nos genes, o que pode bloquear o desenvolvimento de pesquisas relativas a essas informações.

Esse descontentamento, que abrangeu vários países da Europa, Canadá, Austrália e Nova Zelândia, culminou na apresentação oficial, por alguns institutos localizados em países europeus, de oposição às patentes, alegando problemas estruturais destas, tais como ausência de novidade, ato inventivo e de aplicação industrial, bem como insuficiência na descrição das patentes.

Essa situação culminou em disputa judicial iniciada pela Association for Molecular Pathology (AMP) contra a Myriad, alegando que as suas patentes eram inválidas, infringindo o U.S. Patent Act - lei americana sobre patentes. Tal disputa será analisada a seguir, juntamente com os desdobramentos gerados pela decisão da Suprema Corte dos Estados Unidos.

\subsection{Decisão da Suprema Corte dos Estados Unidos: a mudança de um paradigma}

A ação ajuizada pela Association for Molecular Pathology (AMP) contra a Myriad tinha como alegação principal a invalidade das patentes da ré segundo a legislação americana. Em primeira instância, a Corte Distrital acolheu os argumentos da autora, concluindo que as patentes eram inválidas pois se referiam a produtos da natureza. Entretanto, em segunda instância houve reversão da decisão, entendendo-se que as patentes eram válidas. Devido à interposição de recurso pela AMP, coube à Suprema Corte proferir a decisão final acerca do litígio, que ocorreu em 13 de junho de 2013.

Conforme já explicitado, a Myriad detinha nove patentes relacionadas aos genes BRCA1 e 2, mas somente três dessas patentes foram questionadas no caso em comento. A Suprema Corte delimitou de forma bem clara quais eram as patentes em questão, sendo duas relativas a

\footnotetext{
22 PARADISE, Jordan. European opposition to exclusive control over predictive breast câncer testing and the inherent implications for U.S. Patent Law and public policy: a case study of the Myriad Genetics' BRCA patente controversy. Food and drug Law journal, v. 59, n.1, 2004. p. 149-150. Disponível em: <http://papers.ssrn.com/sol3/papers.cfm?abstract_id=897507> Acesso em: 01 out. 2015.
} 
IMPACTOS DA DECISÃO DA SUPREMA CORTE DOS ESTADOS UNIDOS NA PROTEÇÃO DO PATRIMÔNIO GENÉTICO HUMANO: caso Association for Molecular Pathology vs. Myriad Genetics

Beatriz Souza Costa, nathalia Bastos do Vale Brito

DNA isolado que codifica o BRCA1 e BRCA2 e uma terceira cujo objeto consiste no cDNA ${ }^{23}$, submetendo tais patentes a uma análise distinta, considerando as duas primeiras inválidas, e a última, válida.

A questão central enfrentada pela Suprema Corte consistiu na discussão se a ação de isolar o DNA seria suficiente para caracterizá-la como invenção, fruto da atividade humana e, consequentemente patenteável. A decisão proferida em segunda instância, que não foi unânime em suas fundamentações, entendeu, em suma, que a molécula de DNA é composta por ligações químicas que devem ser rompidas quando do isolamento de alguma sequência e o resultado de tal processo é a criação de uma molécula com composições químicas únicas, sendo, portanto, patenteáveis. Quanto ao cDNA, concordaram que ele não pode ser isolado, mas apenas criado em laboratório, sendo totalmente sintético e, consequentemente, uma invenção patenteável. ${ }^{24}$

Para refutar a primeira decisão da segunda instância, a Suprema Corte trouxe o conteúdo da lei sobre patentes americana, explicitando que estas serão concedidas àquele que inventar um produto novo e útil, expressão que traz uma exceção implícita, construída jurisprudencialmente, de não considerar patenteáveis as leis da natureza, os fenômenos naturais e as ideias abstratas. Citando o que foi proferido na decisão Mayo vs. Prometheus ${ }^{25}$, a Suprema Corte entendeu que tais exceções tem a razão de ser devido ao fato de que,

Elas são as ferramentas básicas do trabalho científico e tecnológico" [...] sem essa exceção, haveria considerável risco de que a concessão de patentes iria "amarrar" o uso de tais ferramentas e assim "inibir inovações futuras inovações baseadas nelas". (tradução nossa). ${ }^{26} 27$

${ }^{23}$ O cDNA, conforme explicado em termos gerais no acórdão (UNITED STATES, 2013), se refere ao complementary DNA, um fragmento de DNA criado sinteticamente que possui as mesmas informações para a codificação de proteínas que o DNA natural, mas não possui certos elementos encontrados no DNA. Este tem o formato de dupla hélice, que contém dois nucleotídeos, sendo que esses contém as informações necessárias para criar as ligações de aminoácidos que são utilizados para construir as proteínas do corpo. Entretanto, alguns nucleotídeos não codificam aminoácidos, são conhecidos como íntrons, enquanto os que codificam são os éxons, sendo que o cDNA apenas possui na sua composição esses últimos.

${ }^{24}$ UNITED STATES. Supreme Court. 59 US (2013). Association for Molecular Pathology, et al., Petitioners v. Myriad Genetics, Inc., et al. On writ of certiorari to the United States Court of Appeals for the Federal Circuit. $\quad$ p. 1-3. 1 Disponível em: <http://www.lawupdates.com/pdf/postings/patent/Association_for_Molecular_Pathology_v._Myriad_Gen etics_Inc_._-_Supreme_Court_-_June_13,_2013_.pdf> Acesso em: 20 set. 2015

${ }^{25}$ UNITED STATES. Supreme Court. 566 U.S. (2012). Mayo Collaborative Services, DBA Mayo Medical Laboratories, et al., Petitioners v. Prometheus Laboratories, Inc. On writ of certiorari to the United States Court of Appeals for the Federal Circuit. Disponível em: <http://www.supremecourt.gov/opinions/11pdf/10-1150.pdf>. Acesso em: 20 set. 2015.

${ }^{26}$ UNITED STATES. Supreme Court. 59 US (2013). Association for Molecular Pathology, et al., Petitioners v. Myriad Genetics, Inc., et al. On writ of certiorari to the United States Court of Appeals for the Federal Circuit. p. 11. 
IMPACTOS DA DECISÃO DA SUPREMA CORTE DOS ESTADOS UNIDOS NA PROTEÇÃO DO PATRIMÔNIO GENÉTICO HUMANO: caso Association for Molecular Pathology vs. Myriad Genetics

Beatriz Souza Costa, nathalia Bastos do Vale Brito

Essas exceções implícitas na legislação americana expõem uma das dificuldades relacionadas ao patenteamento da biotecnologia, que é aferir a ocorrência dos requisitos essenciais à patente - novidade, atividade inventiva e aplicação industrial - pelo fato de que os produtos constituem-se em substâncias biológicas, seres vivos e micro-organismos que se modificam e possuem ciclo vital. Conforme Maria Dal Poz e Denis Borges Barbosa ${ }^{28}$, essa dinâmica dos produtos biotecnológicos reduz a estabilidade destes como objetos físicos da tecnologia, dificultando a averiguação da repetibilidade da solução técnica trazida pela invenção, que é um dos pressupostos da aplicação industrial das patentes.

A aferição dos requisitos das patentes é essencial para que não se conceda exclusividade de exploração a alguém de forma indevida, subvertendo os objetivos da patente, que foram bem apontados na decisão em questão ${ }^{29}$, que considerou como objetivo da proteção patentária a criação de incentivos para que as pesquisas e criações continuem sendo desenvolvidas, buscando-se evitar concessões indevidas que podem impedir o fluxo de informações, atrasar pesquisas e dificultar a criação de invenções.

0 fato é que a patente gera um direito de exclusividade de exploração a alguém que criou um invento, obrigando-o, em contrapartida, a divulgar detalhes técnicos acerca de sua obra. Em tese, esta divulgação possibilitaria que outras pessoas desenvolvessem novas pesquisas baseadas neste conhecimento, havendo um verdadeiro fluxo de informação e estímulo à competitividade na criação de novos inventos ${ }^{30}$. Entretanto, se a patente versar sobre um objeto vago ou amplo demais, essa competitividade é prejudicada na medida em que o substrato no qual será feita novas pesquisas poderá ser considerado como violação de patentes.

Quando a Corte considerou que as exceções são verdadeiros instrumentos utilizados por pesquisadores, entendeu que tais exceções não devem ser interpretados de forma tão ampla, já que quaisquer invenções utilizam ou aplicam, em certo grau, as leis da natureza, os fenômenos e

\footnotetext{
${ }^{27}$ They are the basic tools of scientific and technological work [...] without this exception, there would be considerable danger that the grant of patents would tie up the use of such tools and thereby inhibit future innovation premised upon them.

${ }^{28}$ DAL POZ, Maria Ester; BARBOSA, Denis Borges. Incertezas e riscos no patenteamento de biotecnologias: a situação brasileira corrente. In: IACOMINI, Vanessa (Coord.). Propriedade intelectual e biotecnologia. Curitiba: Juruá, 2009. p. 95.

${ }^{29}$ UNITED STATES. Supreme Court. 59 US (2013). Association for Molecular Pathology, et al., Petitioners v. Myriad Genetics, Inc., et al. On writ of certiorari to the United States Court of Appeals for the Federal Circuit. p. 11.

${ }^{30}$ HIMANSHU, Vijay Kumar. Patent law and biotechnological inventions: reconciling proprietary right with global concern for food security, public health and environment. Saarbrüken: LAP Lambert academic publishing Gmbh\&Co. KG, 2012. p. 56-58.
} 
IMPACTOS DA DECISÃO DA SUPREMA CORTE DOS ESTADOS UNIDOS NA PROTEÇÃO DO PATRIMÔNIO GENÉTICO HUMANO: caso Association for Molecular Pathology vs. Myriad Genetics

Beatriz Souza Costa, nathalia Bastos do Vale Brito

as ideias abstratas. Assim, como o cientista pode se ver privado do seu meio de trabalho caso essas exceções sejam patenteadas, analogamente, se caso patenteia-se um organismo vivo sem que este seja diferente do que ocorre na natureza, é impossível realizar quaisquer pesquisas envolvendo tal organismo sem que haja infringência da patente.

Esse fato é um dos motivos pelos quais foi considerado de grande necessidade a averiguação se as patentes em questão realmente são invenções ou são um fenômeno natural.

A Suprema Corte entendeu ser incontroverso o fato de que a sequência genética isolada por Myriad existe na natureza, não havendo criação ou alteração de nenhuma informação codificada pelo gene BRCA1 e BRCA2, nem modificação em suas estruturas ou de sua composição química. Assim,

Neste caso, [...], Myriad não criou nada. Para ser claro, ela encontrou um importante e útil gene, mas separar este gene de seu material genético circundante não é um ato de invenção. Descobertas pioneiras, novas ou até ${ }_{32}$ brilhantes não satisfazem o requisito do $\$ 101$ por ela mesma. (tradução nossa). ${ }^{31}$

Conforme salienta a Suprema Corte $^{33}$, a própria descrição da patente demonstra os problemas no seu objeto, na medida em que a Myriad se refere a ele sempre como descoberta e não invenção. Ademais, o esforço realizado pelos pesquisadores no processo de isolamento e sequenciamento dos genes não é suficiente para satisfazer os requisitos de patenteamento.

Nesse sentido, sempre paira a questão se os organismos vivos podem ser inventados ou tão somente descobertos, o que demanda, para a sua discussão, a delimitação de cada um destes conceitos.

Conforme explica Denis Borges Barbosa ${ }^{34}$, a invenção diz respeito a uma ação humana de intervenção na natureza, gerando uma solução técnica para um problema. Pressupõe-se, então, uma intervenção na natureza que seja capaz de modificá-la para que se possa satisfazer às necessidades sociais materializadas em problemas técnicos.

${ }^{31}$ UNITED STATES. Supreme Court. 59 US (2013). Association for Molecular Pathology, et al., Petitioners v. Myriad Genetics, Inc., et al. On writ of certiorari to the United States Court of Appeals for the Federal Circuit. p. 12.

32 In this case, [...], Myriad did not create anything. To be sure, it found an importante and useful gene, but separating that gene from its surrounding genetic material is not na act of invention. Groundbreaking, innovative or even brilliant Discovery does not by itself satisfy the $\$ 101$ inquiry.

${ }^{33}$ UNITED STATES. Supreme Court. 59 US (2013). Association for Molecular Pathology, et al., Petitioners v. Myriad Genetics, Inc., et al. On writ of certiorari to the United States Court of Appeals for the Federal Circuit. p. 13-14.

${ }^{34}$ BARBOSA, Denis Borges. Uma Introdução à Propriedade Intelectual. 2. ed. Rio de Janeiro: Lumen Juris, 2003. p. 296. 
IMPACTOS DA DECISÃO DA SUPREMA CORTE DOS ESTADOS UNIDOS NA PROTEÇÃO DO PATRIMÔNIO GENÉTICO HUMANO: casO Association for Molecular Pathology vs. Myriad Genetics

Beatriz Souza Costa, nathalia Bastos do Vale Brito

Diferentemente da invenção, a descoberta refere-se à revelação de propriedades, fenômenos, causas, processos naturais e espécies da biodiversidade que existem na natureza mas eram previamente desconhecidas pelo homem. 0 autor Vijay Himanshu ${ }^{35}$ entende que a descoberta pode se constituir em instrumento viabilizador de uma invenção, mas esta tem que ter aplicabilidade e conter características que demonstrem a engenhosidade humana.

No tocante à biotecnologia genética, a dificuldade encontra-se em delimitar quando a atividade empregada pelo homem é suficientemente inovadora para se conceder a patente. No caso em comento, a Suprema Corte entendeu que não houve criação de nada novo que possibilitasse a concessão de uma patente, houve apenas a descoberta de uma informação importante para a saúde pública.

Não há como conceber a atividade de sequenciamento e do isolamento de um fragmento de DNA, mesmo que trabalhosa, como um ato inventivo, visto que são apenas processos usuais que ocorrem nas pesquisas genéticas e, no caso em comento, essa atividade não possibilitou a alteração das informações e características presentes nos genes, inexistindo um produto que tenha aplicação prática para a solução de alguma necessidade humana.

Concebe-se que ao classificar certo produto como invenção, este deve possuir características em si, ou por si só, que possibilitem a aplicação prática para solucionar problemas. A mera informação, como no caso dos genes patenteados, mesmo que importante, não é capaz de modificar ou interferir em nada, ela é apenas um dado propiciador para a busca das verdadeiras soluções, que se materializam, por exemplo, como métodos de diagnósticos, terapias, medicamentos. Portanto, tal informação não tem aplicação por si própria, não devendo ser patenteada.

Assim, a Suprema Corte entendeu serem inválidas as patentes sobre os genes BRCA1 e 2, por não se constituírem em invenções, mas são apenas produtos da natureza. Sustentando enfaticamente que "genes e a informação que eles codificam não são suscetíveis de patentes sob o $\$ 101$ simplesmente porque eles foram isolados do material genético que os circundam". ${ }^{36} 37$

Com essa decisão, a Suprema Corte gera um novo precedente para a interpretação das patentes relacionadas à biotecnologia, modificando o entendimento do que se considera como

\footnotetext{
${ }^{35}$ HIMANSHU, Vijay Kumar. Patent law and biotechnological inventions: reconciling proprietary right with global concern for food security, public health and environment. p. 4-7.

${ }^{36}$ UNITED STATES. Supreme Court. 59 US (2013). Association for Molecular Pathology, et al., Petitioners v. Myriad Genetics, Inc., et al. On writ of certiorari to the United States Court of Appeals for the Federal Circuit. p. 18.

${ }^{37}$ Genes and the information they encode are not patent eligible under \$101 simply because they have been isolated from the surrounding genetic material.
} 
IMPACTOS DA DECISÃO DA SUPREMA CORTE DOS ESTADOS UNIDOS NA PROTEÇÃO DO PATRIMÔNIO GENÉTICO HUMANO: caso Association for Molecular Pathology vs. Myriad Genetics

Beatriz Souza Costa, nathalia Bastos do Vale Brito

invenção e do que é descoberta, tendo em vista a incompatibilidade do sistema de patentes com esta última. Assim, o enrijecimento da análise dos requisitos para a concessão de patentes possibilitará avaliações mais criteriosas, diminuindo o risco de se patentear métodos ou produtos que não se constituem em invenção, o que descaracteriza todo o sistema de patentes e enfraquece o seu propósito.

Posicionamento contrário foi dado à patente sobre o cDNA, pois entendeu-se que pelo fato de este ser sintético e não possuir o elemento íntron em sua molécula, o cDNA não é encontrado na natureza e, assim, há a criação de algo novo ${ }^{38}$.

A fundamentação acerca da validade dessa patente não foi aprofundada na decisão, não se cogitou acerca da utilidade ou da aplicação prática de tal invento, dando ênfase apenas no fato de que o produto em questão é artificial e diferente do que ocorre na natureza. Ao fazer esta análise mais superficial, perdeu-se a oportunidade de aclarar, como ocorreu com as patentes sobre o BRCA1 e 2, a interpretação dos requisitos das patentes e, consequentemente preservar de forma mais efetiva as finalidades das patentes. Neste âmbito, portanto, a interpretação ainda terá de enfrentar desafios. Pelo fato de o cDNA ser uma molécula sintética, ele não será objeto da análise a ser feita no próximo tópico.

Percebe-se que tal decisão foi bastante objetiva, trazendo apenas fundamentações legais e de interpretação jurisprudencial dos requisitos formais das patentes, não englobando argumentos de cunho social, econômico ou relativos à bioética. Assim, por ser uma decisão paradigmática, que foi na contramão da prática costumeira do USPTO e do entendimento jurisprudencial num assunto tão delicado, indaga-se qual o impacto desta decisão na proteção do patrimônio genético humano como elemento da biodiversidade.

\subsection{Invalidação das patentes sobre DNA isolado e proteção do patrimônio genético humano: considerações bioéticas}

Os avanços tecnológicos sob os quais o ser humano está submetido atualmente geram muitos questionamentos e incertezas. O homem ultrapassou barreiras nunca antes imaginadas, 0 que dificulta a assimilação e avaliação dos desdobramentos possíveis a respeito desta situação. É fato que muitas pesquisas e criações representam benefícios à humanidade, mas especialmente

${ }^{38}$ UNITED STATES. Supreme Court. 59 US (2013). Association for Molecular Pathology, et al., Petitioners v. Myriad Genetics, Inc., et al. On writ of certiorari to the United States Court of Appeals for the Federal Circuit. p. 16-17. 
IMPACTOS DA DECISÃO DA SUPREMA CORTE DOS ESTADOS UNIDOS NA PROTEÇÃO DO PATRIMÔNIO GENÉTICO HUMANO: caso Association for Molecular Pathology vs. Myriad Genetics

Beatriz Souza Costa, nathalia Bastos do Vale Brito

na delicada questão da utilização biotecnológica do patrimônio genético humano, cabe-se questionar até que ponto tais benefícios ou utilidades podem ser considerados como ética, moral, social ou juridicamente aceitáveis.

Frente a essas mudanças e questionamentos, os autores Bruno Naves e Marcela Silva ${ }^{39}$ entendem que é perceptível a insuficiência do positivismo clássico para lidar com essa nova realidade, impondo-se ao Direito uma abertura ética que se fundamente nos princípios jurídicos para responder aos anseios da sociedade globalizada, altamente complexa, sendo imprescindível que o Direito se baseie na valorização da dignidade humana e na busca da manutenção do meio ambiente equilibrado e do desenvolvimento sustentável.

Nesse âmbito, cumpre discutir acerca da proteção do patrimônio genético humano como elemento da biodiversidade e do meio ambiente sob o viés da bioética, considerando a contribuição da decisão da Suprema Corte para sua efetivação.

Internacionalmente, vários são os instrumentos legais utilizados para a proteção da dignidade humana em de vários e amplos aspectos. No que concerne à genética, a Declaração Universal sobre o Genoma Humano e os Direitos Humanos ${ }^{40}$ estabelece importantes diretrizes. Cumpre-se destacar, conforme salienta Shawn Harmon ${ }^{41}$, que tal declaração não é apenas um guia ético mas sim um instrumento legal que materializa um compromisso internacional para a adoção de políticas no que concerne à proteção do genoma humano.

Essa declaração considera o genoma humano como a base fundamental da espécie humana, sendo inerente à sua diversidade e dignidade, sendo que a proteção desta dignidade humana é o centro das suas considerações. O genoma humano é elevado a patrimônio da humanidade e como tal deve ser protegido, sendo necessário o respeito ao ser humano considerado como um ente autônomo e também como pertencente à espécie humana em seu conjunto, considerando também as gerações vindouras. ${ }^{42}$

\footnotetext{
${ }^{39}$ NAVES, Bruno Torquato de Oliveira; SILVA, Marcela Vitoriano e. Organismos geneticamente modificados sob a perspectiva da tutela das gerações futuras. Veredas do Direito, Belo Horizonte, v. 11, n. 22, p. 357. 2014. Disponível em: < http://www.domhelder.edu.br/revista/index.php/veredas/article/view/473/428> Acesso em: 04 out. 2015.

40 UNESCO. Declaração Universal sobre o Genoma Humano e os Direitos Humanos. 1997. Disponível: < http:// unesdoc.unesco.org/images/0012/001229/122990por.pdf> Acesso em: 04 out. 2015.

41 HARMON, Shawn. Ethical rethoric: genomics and the moral contente of UNESCO'S Universal Declarations. University of Endinburgh School of Law Working Paper, n. 27, p. 13. 2011. Disponível em: < http://papers.ssrn.com/sol3/papers.cfm?abstract_id=1948087> Acesso em: 05 out. 2015.

42 ROMEO CASABONA, Carlos María. La genética y la biotecnologia en las fronteras del derecho. Acta Bioethica, Santiago, v. 8, n.2, p. 294. 2002. Disponível em: <http://actabioethica.cl/docs/acta6.pdf>. Acesso em: 04 out. 2015.
} 
IMPACTOS DA DECISÃO DA SUPREMA CORTE DOS ESTADOS UNIDOS NA PROTEÇÃO DO PATRIMÔNIO GENÉTICO HUMANO: casO Association for Molecular Pathology vs. Myriad Genetics

Beatriz Souza Costa, nathalia Bastos do Vale Brito

Shawn Harmon ${ }^{43}$ entende que a declaração traz em seu bojo princípios norteadores, como o da autonomia, solidariedade, equidade, inviolabilidade da vida e democracia. Tais princípios são materializados em disposições que estabelecem a dignidade da pessoa humana e a não redução dos indivíduos às suas características genéticas, a impossibilidade de se apropriar do genoma humano em seu estado natural e fazê-lo objeto de transações financeiras. Há também o fomento para a realização pesquisas de forma socialmente responsável, respeitando a autonomia e dignidade dos indivíduos e os direitos humanos, tendo como finalidade o alívio do sofrimento humano, divulgando e repartindo os benefícios com a sociedade, garantindo-se uma melhor qualidade de vida. ${ }^{44}$

O professor Bruno Naves ${ }^{45}$ atenta para o fato de que a Declaração demanda a cooperação internacional no que tange ao tratamento de pessoas portadoras de doenças genéticas e o respectivo incentivo à pesquisa genética. Isso demonstra que o patrimônio genético não deve ser considerado como intocável, mas sim, deve ser um meio de se buscar uma melhor qualidade de vida e de saúde, garantindo a preservação da espécie humana como integrante da biodiversidade.

Considerando-se, portanto os elementos norteadores trazidos por tal declaração cumpre, neste momento, tecer alguns comentários acerca da bioética e da dignidade da pessoa humana para que possamos entender o significado da Decisão da Suprema Corte na proteção do patrimônio genético humano.

O termo bioética foi utilizado pela primeira vez por Fritz Jahr em 1927, referindo-se à junção das palavras gregas bios, que significa vida e ethos que se refere à comportamento ${ }^{46}$. Maria de Fátima Freire de Sá e Bruno Torquato de Oliveira Naves explicam que "Jahr, na esteira da filosofia moral kantiana, propôs um imperativo bioético de respeito a todas as formas de vida, como um fim em si mesmas". ${ }^{47}$

\footnotetext{
43 HARMON, Shawn. Ethical rethoric: genomics and the moral contente of UNESCO'S Universal Declarations. p. 2.

${ }^{44}$ UNESCO. Declaração Universal sobre o Genoma Humano e os Direitos Humanos. 1997.

${ }^{45}$ NAVES, Bruno Torquato de Oliveira. Direitos de personalidade e dados genéticos: revisão críticodiscursiva dos direitos de personalidade à luz da "natureza jurídica" dos dados genéticos humanos. p. 44. ${ }^{46}$ SÁ, Maria de Fátima Freire de; NAVES, Bruno Torquato de Oliveira. Manual de biodireito. 3. ed. Belo Horizonte: Del Rey, 2015. p. 7.

${ }^{47}$ SÁ, Maria de Fátima Freire de; NAVES, Bruno Torquato de Oliveira. Manual de biodireito. p. 7.
} 
IMPACTOS DA DECISÃO DA SUPREMA CORTE DOS ESTADOS UNIDOS NA PROTEÇÃO DO PATRIMÔNIO GENÉTICO HUMANO: caso Association for Molecular Pathology vs. Myriad Genetics

Beatriz Souza Costa, nathalia Bastos do Vale Brito

Entretanto, foi através de Van Rensselaer Potter em 1971 que o termo bioética foi melhor divulgado, sendo que seu significado é o estudo da moralidade das condutas humanas nas ciências biológicas, discutindo-se acerca dos limites éticos que devem ser observados. ${ }^{48}$

A bioética busca respostas para indagações surgidas com o desenvolvimento científico e tecnológico, cogitando-se tanto da proteção da vida e dignidade humana como da proteção do meio ambiente, impondo deveres de responsabilidade e prudência. Neste sentido, Carlos Romeo Casabona $^{49}$ entende que a bioética constitui-se em um verdadeiro instrumento de reflexão, discussão e elaboração de critérios limitadores e orientadores na atuação dos pesquisadores. Assim, a bioética “desde seu nascedouro, abrange também questões de uma ética ecológica, que deve ser capaz de avaliar as relações do homem com o meio ambiente em pressupostos de sustentabilidade". 50

Um dos conceitos centrais na discussão bioética é a dignidade da pessoa humana, que possui um profundo conteúdo ético, axiológico e uma dimensão histórico-cultural. Conforme Kildare Carvalho ${ }^{51}$, a dignidade é uma qualidade intrínseca dos indivíduos e se refere ao respeito que cada um deles merece como pessoa. Segundo ele ${ }^{52}$ a dignidade da pessoa humana fundamenta-se na autodeterminação e na autonomia individual, já que cada pessoa, por ser racional, é capaz de se guiar pelas suas conjecturas, permitindo-lhe o exercício de sua liberdade. Assim, “o homem constrói cotidianamente o sentido de sua existência, dialogando com elementos díspares, paradoxais, contraditórios. A existência humana se afirma, portanto, entre tensões e busca de equilíbrio, como base de orientação para o agir humano". ${ }^{53}$

Quando se trata de dignidade da pessoa humana, imperioso destacar o pensamento kantiano, no qual o homem não pode ser entendido como um meio, mas como um fim em si mesmo. Em suas palavras,

\footnotetext{
${ }^{48}$ PINTO, Gerson Neves. A invenção da bioética. Scientia luris, Londrina, v. 18, n. 2, 212. 2014. Disponível em < http://www.uel.br/revistas/uel/index.php/iuris/article/view/16678> Acesso em: 03 out. 2015.

${ }^{49}$ ROMEO CASABONA, Carlos María. 0 direito biomédico e a bioética. In: ROMEO CASABONA, Carlos María; QUEIROZ, Juliane Fernandes (Coord.). Biotecnologia e suas implicações ético-jurídicas. Belo Horizonte: Del Rey, 2005. p. 19.

${ }^{50}$ SÁ, Maria de Fátima Freire de; NAVES, Bruno Torquato de Oliveira. Manual de biodireito. p. 8.

${ }^{51}$ CARVALHO, Kildare Gonçalves. Direito constitucional: teoria do Estado e da Constituição, Direito constitucional positivo. 17. ed. rev., atu., amp. Belo Horizonte: Del Rey, 2011. p. 582-583.

52 CARVALHO, Kildare Gonçalves. Direito constitucional: teoria do Estado e da Constituição, Direito constitucional positivo. p. 582-583.

${ }^{53}$ CARVALHO, Kildare Gonçalves. Direito constitucional: teoria do Estado e da Constituição, Direito constitucional positivo. p. 583.
} 
IMPACTOS DA DECISÃO DA SUPREMA CORTE DOS ESTADOS UNIDOS NA PROTEÇÃO DO PATRIMÔNIO GENÉTICO HUMANO: caso Association for Molecular Pathology vs. Myriad Genetics

Beatriz Souza Costa, Nathalia Bastos do Vale Brito

O homem, e, duma maneira geral, todo o ser racional, existe como fim em si mesmo, não só como meio para o uso arbitrário desta ou daquela vontade. Pelo contrário, em todas as suas acções, tanto nas que se dirigem a ele mesmo como nas que se dirigem a outros seres racionais, ele tem sempre de ser considerado simultaneamente como fim. ${ }^{54}$

Para o filósofo, a dignidade é incompatível com o preço, ou seja, quando não se é possível atribuir preço a algo, substituindo por alguma coisa equivalente, este algo possui dignidade, por estar acima de qualquer preço, possuindo um valor intrínseco, sendo um fim em si mesmo. ${ }^{55}$

A dignidade em Kant é um princípio universal, válido para todos, constituindo-se em um imperativo, ou seja, um mandamento que expressa a necessidade objetiva da ação. Ademais, é um imperativo categórico, no sentido de que determina a vontade não para obter um efeito esperado ou desejado, mas determina a vontade como vontade, valendo para todos os seres humanos incondicionalmente. A dignidade demanda agir “[...] de modo a considerar a humanidade, seja na tua pessoa, seja na pessoa de qualquer outro, sempre também como objetivo e nunca como um simples meio."56

Roberto Andorno ${ }^{57}$ entende que a dignidade humana possui um reconhecimento universal, entendendo-se que o homem possui valor incondicional e é titular de direitos pelo simples fato de fazer parte da humanidade, constituindo-se em base dos direitos humanos. Entende o autor que essa ampla aceitação da dignidade faz com que se considere que ela seja "a última barreira às intervenções biotecnológicas irreversíveis em nossa própria natureza," ${ }^{58}$ apesar de possuir uma aceitação um pouco controversa pela bioética, já que a dificuldade de definição do seu conceito frente aos novos desafios trazidos pela conhecimento técnicocientífico faz com que diferentes formas de justificação sejam desenvolvidas para argumentação frente aos problemas enfrentados.

\footnotetext{
${ }^{54}$ KANT, Immanuel. Fundamentação da metafísica dos costumes. Lisboa: Edições 70, 2007. p. 68.

${ }^{55}$ KANT, Immanuel. Fundamentação da metafísica dos costumes. p. 69.

56 ANTISERI, Dario; REALE, Giovanni. História da filosofia: de Spinoza a Kant, v. 4. São Paulo: Paulus, 2005. p. 376.

${ }^{57}$ ANDORNO, Roberto. A noção paradoxal de dignidade humana. Revista bioética, Brasília, v. 17, n.3, p.435-436. $2009 . \quad$ mar. 2 em: http://revistabioetica.cfm.org.br/index.php/revista_bioetica/article/viewFile/509/510> Acesso em: 03 out. 2015.

${ }^{58}$ ANDORNO, Roberto. A noção paradoxal de dignidade humana. p. 435.
} 
IMPACTOS DA DECISÃO DA SUPREMA CORTE DOS ESTADOS UNIDOS NA PROTEÇÃO DO PATRIMÔNIO GENÉTICO HUMANO: caso Association for Molecular Pathology vs. Myriad Genetics

Beatriz Souza Costa, nathalia Bastos do Vale Brito

Tendo em vistas estas breves considerações acerca da dignidade da pessoa humana, questiona-se a possibilidade do material genético humano ser objeto de uma patente e se isso implicaria na sua utilização como meio para conseguir uma vantagem econômica.

$O$ debate principal nesse quesito diz respeito ao questionamento se a patenteabilidade do material genético significa a mercantilização da vida humana, com consequente desvalorização da sua dignidade. Stephanie Constand ${ }^{59}$, ao explicar o debate acerca dessa assertiva, contrapõe duas concepções dominantes. A primeira, baseada na dignidade intrínseca do homem segundo a ética kantiana, defende que o valor que o ser humano possui não pode ser quantificado economicamente, considerando que o patenteamento dos genes humanos viola a essência do que significa ser humano. Contrariamente, entende-se que dar valor econômico a partes do corpo humano não significa necessariamente mercantilizar um indivíduo. Ademais, a concessão de patentes não significa a apropriação de parte do ser humano, pois não há direito de propriedade na patente, mas sim um direito de exclusividade de exploração. Lever ${ }^{60}$ explica que há um direito à exclusão, impedindo que outros utilizem o invento patenteado, mas não há um direito de propriedade sobre esse invento.

Para compreender o embate e trazer esclarecimentos ao questionamento abordado acima, cumpre tecer considerações acerca da apropriação no direito das patentes e da irredutibilidade do ser humano à sua composição biológica.

Primeiramente, o direito das patentes pode gerar certas dúvidas acerca de sua natureza jurídica mas, em suma, a patente não significa apropriação do que foi inventado, mas identificase com o direito de exclusividade de exploração sendo, em tese, instrumento para a divulgação de informações que incentivarão novas pesquisas.

Entretanto, as patentes dizem respeito apenas às invenções e no tocante ao material genético, a simples descoberta de informações não a leva a ser considerado como invenção. 0 que se via antes da decisão do caso Myriad era o patenteamento do DNA isolado, que não é invenção, é apenas a clarificação de uma informação. Assim, mesmo que se entenda que o patenteamento não é uma apropriação de parte do ser humano, essa prática só pode ser realizada se há a ocorrência de invento, pois não é possível a concessão de um direito de

${ }^{59}$ CONSTAND, Stephanie. Patently a problem? Human gene patenting and its ethical and practical implications. Sydney Law School legal studies research paper, n. 13, p. 12-13. 2003. Disponível em: < http: / / papers.ssrn.com/sol3/papers.cfm?abstract_id=2346568>. Acesso em: 04 out. 2015.

${ }^{60}$ LEVER, Anabelle. Is it ethical to patente human genes?. Intellectual property and theories of justice. United Kingdom: Palgrave MacMillan, p. 5-6. 2008. Disponível em: < http://papers.ssrn.com/sol3/papers.cfm?abstract_id=2507527> Acesso em: 03 out. 2015. 
IMPACTOS DA DECISÃO DA SUPREMA CORTE DOS ESTADOS UNIDOS NA PROTEÇÃO DO PATRIMÔNIO GENÉTICO HUMANO: casO Association for Molecular Pathology vs. Myriad Genetics

Beatriz Souza Costa, nathalia Bastos do Vale Brito

exclusividade a um material genético da forma em que ele é encontrado na natureza. Isso é expressamente vedado na Declaração Universal sobre o Genoma Humano. ${ }^{61}$

Em segundo lugar, cumpre salientar que não é possível considerar que o ser humano seja reduzido às suas informações genéticas. Roberto Andorno entende que esse reducionismo acaba por negar a dignidade intrínseca do homem pois é insensato falar em dignidade humana a um conjunto orgânico, sendo inconcebível conceder dignidade a esses elementos. "Se não reconhecermos nenhum tipo de elemento espiritual na configuração de cada indivíduo, parece extremamente difícil, se não impossível, sustentar a ideia de dignidade humana.”62

O ser humano, então, é muito mais do que sua constituição biológica - compreende a sua complexidade psíquica, sua autodeterminação, sua caracterização como um ser cultural, etc. - e, neste sentido, a utilização e a pesquisa com o material genético não pode ser acusada de violadora da dignidade simplesmente porque tem como instrumento uma parte do ser humano. O tratamento dessa questão deve atentar-se para não ocorrer, conforme defende Carlos Romeo Casabona ${ }^{63}$ uma sacralização do patrimônio genético, de modo a deixá-lo intocável, pois há que se reconhecer a importância das pesquisas que utilizam o genoma humano, na medida em que auxiliam na prevenção e tratamento de enfermidades e melhoram a qualidade de vida do ser humano, garantindo-se dessa forma o direito à saúde, imprescindível à dignidade.

Entretanto, a concessão de patentes sobre o material genético humano isolado e sequenciado, além de ser indevido sob os fundamentos da patente, também não pode ser considerado como atinente à dignidade da pessoa humana, já que a informação genética da forma como ela se encontra naturalmente é de acesso a todos e não pode ser explorada de forma exclusiva.

Assim, a consideração de que não é atividade inventiva o simples isolamento e sequenciamento do DNA, contribui para que se evite o patenteamento indevido, entendendo que este, além de ferir a proteção do patrimônio genético humano, viola os princípios atinentes à liberdade de informação e de pesquisa com o patrimônio genético humano, na medida em que o patenteamento de uma informação impede que outros cientistas tenham acesso a esta e possam desenvolver novas pesquisas. Além disso, o patenteamento pode causar embaraços ao acesso à

${ }^{61}$ UNESCO. Declaração Universal sobre o Genoma Humano e os Direitos Humanos. 1997. Disponível: < http://unesdoc.unesco.org/images/0012/001229/122990por.pdf> Acesso em: 04 out. 2015.

${ }^{62}$ ANDORNO, Roberto. A noção paradoxal de dignidade humana. p. 443.

${ }^{63}$ ROMEO CASABONA, Carlos María. La genética y la biotecnologia en las fronteras del derecho. p. 294. 
IMPACTOS DA DECISÃO DA SUPREMA CORTE DOS ESTADOS UNIDOS NA PROTEÇÃO DO PATRIMÔNIO GENÉTICO HUMANO: caso Association for Molecular Pathology vs. Myriad Genetics

Beatriz Souza Costa, nathalia Bastos do Vale Brito

saúde pública, devido ao encarecimento de testes para diagnósticos de doenças ou tratamentos, o que fere diretamente a dignidade humana.

É possível depreender que a proteção do patrimônio genético não significa a intocabilidade deste e o impedimento à realização de pesquisas, mas está consoante, em verdade, a uma fiscalização de como tais pesquisas estão sendo feitas, quais os efeitos e se eles podem ferir a dignidade humana. Neste âmbito, a importante contribuição da decisão da Suprema Corte dos Estados Unidos está na restrição das possibilidades de patenteamento, ao tornar claro como se deve dar a interpretação de seus requisitos, impedindo que laboratórios como Myriad apoiem mais da metade de seu lucro na exploração dessas patentes em detrimento do avanço das pesquisas e da garantia da saúde e que encobrem uma informação que deve ser de livre acesso a todos, atuação que pode ser considerada como eticamente reprovável.

Cumpre salientar, ademais, que juntamente a essa necessária proteção, há a necessidade de promover o acesso racional a esse patrimônio, de forma a que os benefícios advindos deste estejam disponíveis às diversas populações, como modo de garantir o direito à saúde, a melhorar a qualidade de vida, fatos que são propiciadores do desenvolvimento sustentável e que permitem, por consequência, a proteção do ser humano como espécie e elemento da biodiversidade, garantindo um meio ambiente ecologicamente equilibrado.

\section{CONCLUSÃO}

O presente artigo teve como objeto de estudo central a decisão da Suprema Corte dos Estados Unidos acerca do patenteamento do DNA isolado, analisando-a de forma a compreender qual o impacto gerado na proteção do patrimônio genético como elemento necessário da biodiversidade.

Percebeu-se que o patrimônio genético humano é parte integrante do meio ambiente, constituindo-se num elemento biológico que carrega as informações essenciais para a constituição do ser humano, que é elemento da biodiversidade. A concepção de que o ser humano é parte do meio ambiente e que depende do equilíbrio deste para a própria manutenção de sua vida e das vidas das gerações vindouras é possível a partir da mudança de visão de mundo que vem ocorrendo, a passagem do antropocentrismo para o ecocentrismo possibilita que o ser humano não se veja mais como um ente autônomo que pode subjugar a natureza conforme suas necessidades, mas que compreenda a relação de interdependência estabelecida entre a vida 
IMPACTOS DA DECISÃO DA SUPREMA CORTE DOS ESTADOS UNIDOS NA PROTEÇÃO DO PATRIMÔNIO GENÉTICO HUMANO: casO Association for Molecular Pathology vs. Myriad Genetics

Beatriz Souza Costa, nathalia Bastos do Vale Brito

humana e a totalidade da biodiversidade e dos ecossistemas. Assim, o homem se enxerga como parte do meio ambiente, compreendendo como um de seus deveres a sua proteção e conservação. Ademais, corrobora-se a proteção do patrimônio genético como dever ambiental através dos ditames da Constituição, que o considera como essencial para a garantia e alcance de um meio ambiente equilibrado.

Assim, a proteção do patrimônio como integrante da biodiversidade é de suma importância, pois diz respeito à garantia da manutenção da vida do próprio ser humano, garantindo-lhe dignidade. A busca pelo meio ambiente equilibrado é essencial na sociedade moderna, devendo prezar-se pelas práticas que proporcionem o desenvolvimento sustentável.

Nesse âmbito, as patentes, se adequadamente concedidas a inventos e não a descobertas, desempenham importante papel na difusão e compartilhamento de conhecimento, incentivando a evolução das pesquisas que podem ser benéficas ao ser humano. Entretanto, quando se tem um caso complexo como o do patenteamento do genoma humano, há a dificuldade de sua interpretação sob as regras de propriedade intelectual, podendo gerar a concessão de patentes indevidas. Ademais, cabe também a discussão acerca da bioética, como se dá a interpretação dessas patentes, indagando-se se elas constituem-se em apropriação do ser humano ou se ferem a dignidade da pessoa humana.

Tendo em vista essas indagações, analisou-se a decisão da Suprema Corte dos Estados Unidos, devido à sua importância ao gerar uma nova concepção interpretativa para as patentes sobre DNA isolado.

Os laboratórios Myriad sequenciaram e isolaram o gene BRCA1 e 2, que elevam a probabilidade de se desenvolver câncer de mama e, a partir deste feito, requereram patentes sobre esses genes naturais, sobre genes artificiais e sobre métodos de diagnóstico. Tais patentes geraram muitas controvérsias devido aos impactos negativos sobre as pesquisas genéticas acerca do câncer de mama, pois restringiu-se o uso destes genes como objeto de pesquisa, sujeitando os pesquisadores aos encargos financeiros para obter uma licença de exploração, o que, a longo prazo, representa um atraso ao desenvolvimento de novos tratamentos à doença. A saúde pública também foi afetada por essas patentes, na medida em que somente a Myriad poderia desenvolver e explorar os testes para avaliar se o indivíduo tem predisposição ao câncer, de grande importância na medicina preventiva, sujeitando a população ao alto custo destes e também a impossibilidade de se auferir uma segunda opinião acerca do resultado, constituindose num entrave ao acesso à saúde. 
IMPACTOS DA DECISÃO DA SUPREMA CORTE DOS ESTADOS UNIDOS NA PROTEÇÃO DO PATRIMÔNIO GENÉTICO HUMANO: caso Association for Molecular Pathology vs. Myriad Genetics

Beatriz Souza Costa, nathalia Bastos do Vale Brito

Assim, o debate jurídico acerca da validade das patentes foi decidido pela Suprema Corte que reconheceu a importância do trabalho realizado pela Myriad, mas que o esforço humano depreendido não era capaz de tornar o DNA isolado como matéria patenteável, já que ele não apresentava características distintas e úteis do DNA encontrado na natureza, não podendo ser considerado como invenção. A Suprema Corte invalidou tais patentes, compreendendo-as como elementos naturais que devem ser de livre acesso a todos.

Tal decisão auxilia na proteção do patrimônio genético humano na medida em que restringe $o$ patenteamento deste que, apesar de não poder ser considerado como mercantilização do homem, é indevido por tratar-se de uma informação natural que deve ser de amplo acesso a todos. A compreensão de que o homem não se reduz à sua composição genética permite que a proteção do patrimônio genético não se dê somente quando da sua intocabilidade mas sim, quando há a utilização racional e ética de seus componentes e informações. Compreendendo-se, por fim, que tal atuação ética é aquela que permite o desenvolvimento sustentável através do acesso à saúde e do incentivo às pesquisas genéticas que podem beneficiar o homem, fatores essenciais para a garantia da dignidade da pessoa humana e que contribuem para o alcance de um meio ambiente equilibrado.

\section{REFERÊNCIAS}

ANDORNO, Roberto. A noção paradoxal de dignidade humana. Revista bioética, Brasília, v. 17, n.3, p.435-449. mar. 2009. Disponível em: <

http://revistabioetica.cfm.org.br/index.php/revista_bioetica/article/viewFile/509/510> Acesso em: 03 out. 2015.

ANTISERI, Dario; REALE, Giovanni. História da filosofia: de Spinoza a Kant, v. 4. São Paulo: Paulus, 2005. 433p.

BARBOSA, Denis Borges. Uma Introdução à Propriedade Intelectual. 2. ed. Rio de Janeiro: Lumen Juris, 2003. 951p.

BRASIL. Constituição (1988) Constituição da República Federativa do Brasil. Brasília, 5 out. 1988. Disponível em: <

http://www.planalto.gov.br/ccivil_03/constituicao/ConstituicaoCompilado.htm> Acesso em: 01 out. 2015.

BRASIL. Lei n. 6.938, de 31 de agosto de 1981. Dispõe sobre a Política Nacional do Meio Ambiente, seus fins e mecanismos de formulação e aplicação, e dá outras providências. Diário Oficial da União, Brasília, 31 ago. de 1981. Disponível em: <http://www.planalto.gov.br/ccivil_03/Leis/L6938.htm> Acesso em: 01 out. 2015. 
IMPACTOS DA DECISÃO DA SUPREMA CORTE DOS ESTADOS UNIDOS NA PROTEÇÃO DO PATRIMÔNIO GENÉTICO HUMANO: caso Association for Molecular Pathology vs. Myriad Genetics

Beatriz Souza Costa, nathalia Bastos do Vale Brito

BRASIL, Lei n. 13.123, de 20 de maio de 2015. Regulamenta o inciso II do $\S 10$ e o $\S 40$ do art. 225 da Constituição Federal, o Artigo 1, a alínea j do Artigo 8, a alínea c do Artigo 10, o Artigo 15 e os §§ 30 e 40 do Artigo 16 da Convenção sobre Diversidade Biológica, promulgada pelo Decreto no 2.519, de 16 de março de 1998; dispõe sobre o acesso ao patrimônio genético, sobre a proteção e o acesso ao conhecimento tradicional associado e sobre a repartição de benefícios para conservação e uso sustentável da biodiversidade; revoga a Medida Provisória no 2.186-16, de 23 de agosto de 2001; e dá outras providências. Diário Oficial da União, Brasília, 20 de maio de 2015. Disponível em: < http://www.planalto.gov.br/ccivil_03/_Ato2015-

2018/2015/Lei/L13123.htm\#art50 > Acesso em: 26 nov. 2015.

CARVALHO, Kildare Gonçalves. Direito constitucional: teoria do Estado e da Constituição, Direito constitucional positivo. 17. ed. rev., atu., amp. Belo Horizonte: Del Rey, 2011. 1356p.

CONSTAND, Stephanie. Patently a problem? Human gene patenting and its ethical and practical implications. Sydney Law School legal studies research paper, n. 13, 2003. p.1-26. Disponível em: < http: / /papers.ssrn.com/sol3/papers.cfm?abstract_id=2346568> Acesso em: 04 out. 2015.

DAL POZ, Maria Ester; BARBOSA, Denis Borges. Incertezas e riscos no patenteamento de biotecnologias: a situação brasileira corrente. In: IACOMINI, Vanessa (Coord.). Propriedade intelectual e biotecnologia. Curitiba: Juruá, 2009. p. 93-137.

FIORILLO, Celso Antônio Pacheco. Curso de Direito ambiental brasileiro. 14. ed. São Paulo: Saraiva, 2013.

GUNERATNE, Camena. Genetic resources, equity and international law. Massachusetts: Edward Elgar Publishing, 2012. 323p.

HARMON, Shawn. Ethical rethoric: genomics and the moral contente of UNESCO'S Universal Declarations. University of Endinburgh School of Law Working Paper, n. 27, p. 1-19. 2011. Disponível em: < http://papers.ssrn.com/sol3/papers.cfm?abstract_id=1948087> Acesso em: 05 out. 2015.

HIMANSHU, Vijay Kumar. Patent law and biotechnological inventions: reconciling proprietary right with global concern for food security, public health and environment. Saarbrüken: LAP Lambert academic publishing Gmbh\&Co. KG, 2012. 342p.

IACOMINI, Vanessa. Os direitos de propriedade intelectual e a biotecnologia. In: IACOMINI, Vanessa (coord.). Propriedade intelectual e biotecnologia. Curitiba: Juruá, 2009. p. 13-29.

JOLIE, Angelina. My medical choice. The New York Times, Nova York, 14 mai. 2014. Disponível em: < http://www.nytimes.com/2013/05/14/opinion/my-medical-choice.html?_r=0> Acesso em: 03 out. 2015.

KANT, Immanuel. Fundamentação da metafísica dos costumes. Lisboa: Edições 70, 2007. 119p.

LEVER, Anabelle. Is it ethical to patente human genes?. Intellectual property and theories of justice. United Kingdom: Palgrave MacMillan, p. 1-29. 2008. Disponível em: < http://papers.ssrn.com/sol3/papers.cfm?abstract_id=2507527> Acesso em: 03 out. 2015 
IMPACTOS DA DECISÃO DA SUPREMA CORTE DOS ESTADOS UNIDOS NA PROTEÇÃO DO PATRIMÔNIO GENÉTICO HUMANO: caso Association for Molecular Pathology vs. Myriad Genetics

Beatriz Souza Costa, nathalia Bastos do Vale Brito

MILARÉ, ÉDIS. Direito do ambiente. 9. ed. São Paulo: Revista dos Tribunais, 2014. 1680p.

PARADISE, Jordan. European opposition to exclusive control over predictive breast câncer testing and the inherent implications for U.S. Patent Law and public policy: a case study of the Myriad Genetics' BRCA patente controversy. Food and drug Law journal, v. 59, n.1, p. 132-154. 2004. Disponível em: < http://papers.ssrn.com/sol3/papers.cfm?abstract_id=897507> Acesso em: 01 out. 2015.

NAVES, Bruno Torquato de Oliveira. Direitos de personalidade e dados genéticos: revisão crítico-discursiva dos direitos de personalidade à luz da "natureza jurídica" dos dados genéticos humanos. Belo horizonte: Escola Superior Dom Helder Câmara, ESDHC, 2010. 159p.

NAVES, Bruno Torquato de Oliveira; SILVA, Marcela Vitoriano e. Organismos geneticamente modificados sob a perspectiva da tutela das gerações futuras. Veredas do Direito, Belo Horizonte, v. 11, n. 22, p. 355-380. 2014. Disponível em: < http://www.domhelder.edu.br/revista/index.php/veredas/article/view/473/428> Acesso em: 04 out. 2015.

PINTO, Gerson Neves. A invenção da bioética. Scientia luris, Londrina, v. 18, n. 2, p. 211-227. 2014. Disponível em < http://www.uel.br/revistas/uel/index.php/iuris/article/view/16678> Acesso em: 03 out. 2015.

RAMOS, Ana Virgínia Gabrich Fonseca Freire. Manipulação da vida humana e meio ambiente. Dissertação (Mestrado em Direito) - Escola Superior Dom Helder Câmara, Belo Horizonte. 2014. $120 f$.

RINEHART, Amelia. Myriad lessons learned. University of Utah College of Law Research Paper, n. 87, p. 1-40. 2015. Disponível em: <http://papers.ssrn.com/sol3/papers.cfm?abstract_id=2499789> Acesso em: 23 set. 2015.

ROMEO CASABONA, Carlos María. La genética y la biotecnologia en las fronteras del derecho. Acta Bioethica, Santiago, v. 8, n.2, p. 283-297. 2002. Disponível em: <http://actabioethica.cl/docs/acta6.pdf> Acesso em: 04 out. 2015.

ROMEO CASABONA, Carlos María. O direito biomédico e a bioética. In: ROMEO CASABONA, Carlos María; QUEIROZ, Juliane Fernandes (Coord.). Biotecnologia e suas implicações ético-jurídicas. Belo Horizonte: Del Rey, 2005. p. 13-44.

SÁ, Maria de Fátima Freire de; NAVES, Bruno Torquato de Oliveira. Manual de biodireito. 3. ed. Belo Horizonte: Del Rey, 2015. 432p.

UNESCO. Declaração Universal sobre o Genoma Humano e os Direitos Humanos. 1997. Disponível: < http://unesdoc.unesco.org/images/0012/001229/122990por.pdf> Acesso em: 04 out. 2015.

UNITED STATES PATENT AND TRADEMARK OFFICE. Guidelines for examination of patente applications under the 35 U.S.C 112, $\$ 1^{\circ}$ "Written Description" requirement. Federal Register, v. 66, n. 4, p. 1092-1099. jan. 2001. Disponível em: 
IMPACTOS DA DECISÃO DA SUPREMA CORTE DOS ESTADOS UNIDOS NA PROTEÇÃO DO PATRIMÔNIO GENÉTICO HUMANO: caso Association for Molecular Pathology vs. Myriad Genetics

Beatriz Souza Costa, nathalia Bastos do Vale Brito

<http: //www.uspto.gov/web/offices/com/sol/notices/writdesguide.pdf > Acesso em: 20 set. 2015.

UNITED STATES. Supreme Court. 447 U.S. 303 (1980). Diamond v. Chakrabarty. Disponível em: < http: / /caselaw.lp. findlaw.com/cgi-bin/getcase.pl?court=us\&vol=447\&invol=303> Acesso em: 03 out. 2015.

UNITED STATES. Supreme Court. 566 U.S. (2012). Mayo Collaborative Services, DBA Mayo Medical Laboratories, et al., Petitioners v. Prometheus Laboratories, Inc. On writ of certiorari to the United States Court of Appeals for the Federal Circuit. Disponivel em:

<http://www.supremecourt.gov/opinions/11pdf/10-1150.pdf>. Acesso em: 20 set. 2015.

UNITED STATES. Supreme Court. 59 US (2013). Association for Molecular Pathology, et al., Petitioners v. Myriad Genetics, Inc., et al. On writ of certiorari to the United States Court of Appeals for the Federal Circuit. Disponível em:

<http://www.lawupdates.com/pdf/postings/patent/Association_for_Molecular_Pathology_v._My riad_Genetics_Inc_-_-_Supreme_Court_-_June_13,_2013_.pdf>.Acesso em: 20 set. 2015

Recebido em: 26.11.2016 / Revisões requeridas em: 26.02.2016 / Aprovado em: 02.03.2016 